\title{
STUDI KETERAMPILAN PROSES SAINS FISIKA PESERTA DIDIK SMAN SE-KABUPATEN JENEPONTO
}

\author{
M. Arifuddin Aswar'), Agustinus Jarak Patandean ${ }^{2}$, Herman $^{3)}$ \\ Program Studi Pendidikan Fisika, Jurusan Fisika \\ Fakultas Matematika dan Ilmu Pengetahuan Alam, Universitas Negeri Makassar \\ J1. Malengkeri Raya, Makassar, 90222 \\ Email: udintinggi07@gmail.com
}

\begin{abstract}
Abstrak. Penelitian ini adalah penelitian survei yang bertujuan untuk mengetahui gambaran keterampilan proses sains peserta didik dalam pembelajaran fisika SMAN se-Kabupaten Jeneponto. Variabel dalam penelitian ini adalah keterampilan proses sains. Variabel yang dimaksudkan adalah menafsirkan, meramalkan, menerapkan konsep dan mengomunikasikan. Populasi penelitian ini adalah seluruh peserta didik SMAN se- Kabupaten Jeneponto, dan sampel dalam penelitian ini adalah peserta didik kelas XI dari SMAN yang masing-masing terakreditasi A, B, dan C di Kabupaten Jeneponto. Teknik yang digunakan dalam pengambilan sampel adalah teknik Proportionate Stratified Random Sampling. Analisis deskriptif memberikan kesimpulan bahwa sekolah yang terakreditasi A memiliki keterampilan proses sains peserta didik yang lebih tinggi daripada sekolah yang terakreditasi B dan C, dan sekolah yang terakreditasi B memiliki keterampilan proses sains peserta didik yang lebih tinggi daripada sekolah yang terakreditasi C.
\end{abstract}

\section{Kata Kunci: keterampilan proses sains}

Abstract. This study is a survey research aims to reveal the science process skills learners in teaching high school physics in Jeneponto regency. Single variable in this study is the variable that is meant is interpretating, predicting, concept aplicating and communicate. The study population was all students of class XI senior high school in Jeneponto Regency, and samples in this study were students of class $X I$ of senior high school each accredited $A, B$, and $C$ in Jeneponto Regency. Techniques used in sampling is Proportionate Stratified Random Sampling technique. Descriptive analysis concludes that an accredited school $A$ has the science process skills of students is higher than an accredited school B, and $C$, and $B$ accredited school have the science process skills of students is higher than an accredited school C.

Keywords: Science Process Skills

\section{PENDAHULUAN}

Fisika sebagai salah satu mata pelajaran sains pada setiap jenjang pendidikan dasar terbentuk dan berkembang melalui suatu proses ilmiah, yang juga harus dikembangkan pada peserta didik sebagai pengalaman bermakna. Pengalaman tersebut dapat digunakan peserta didik sebagai bekal perkembangan diri selanjutnya. Pada hakikatnya fisika sebagai mata pelajaran, terdiri atas: (1) fisika sebagai produk; (2) fisika sebagai proses; (3) fisika sebagai sikap; dan (4) fisika sebagai teknologi (Sutrisno, 2006). Sehubungan dengan hakikat fisika di atas, fisika sebagai suatu proses dimaknai bahwa dalam pembelajaran Fisika terdapat keterampilan-keterampilan dasar yang biasa digunakan para ilmuwan dalam bekerja secara ilmiah sehingga mereka mampu memperoleh produk atau pengetahuan yang diharapkan. Perkembangan fisika ditunjang oleh keterampilan proses yang digunakan oleh para ilmuwan, yaitu "Keterampilan Proses Sains". Keterampilan proses sains adalah ciri "metode ilmiah" dari Fisika sebagai Ilmu. Keterampilan proses adalah salah satu bagian kompetensi inti dari empat kompetensi inti yang dimiliki kurikulum 2013. Kurikulum 2013 
mengamanatkan pendekatan sainstifik dalam pembelajaran sebagai suatu proses ilmiah atau kegiatan ilmiah dimana metode ilmiah pada umumnya memuat serangkaian aktivitas pengumpulan data melalui eksperimen atau observasi, mengolah informasi atau data, menganalisis, memformulasikan dan menguji hipotesis. Pendekatan saintifik lebih menekankan pada perkembangan dan pengembangan sikap, keterampilan dan pengetahuan peserta didik yang mengedepankan penalaran induktif di bandingkan penalaran deduktif. Dalam pendekatan saintifik ada lima proses pembelajaran sebagai pengalaman belajar pokok yaitu: Mengamati, menanya, mengumpulkan informasi/eksperimen, mengasosiasikan/mengolah informasi dan mengomunikasikan.

Peserta didik membentuk sendiri pengetahuan mereka secara aktif melalui interaksi dengan lingkungannya karena perkembangan konseptual merupakan hasil dari interaksi antara konsep yang telah ada dengan pengalaman yang baru. Oleh sebab itu, suatu kemampuan proses dapat memberikan kesempatan kepada peserta didik untuk ikut menghayati proses penemuan atau menyusun suatu konsep sebagai suatu kereampilan proses. Dengan demikian suatu proses belajar tidak hanya merupakan transfer pengetahuan saja. Pengetahuan sains (fisika) terdiri atas banyak konsep dan prinsip yang pada umumnya sangat abstrak. Kesulitan yang dihadapi oleh sebagian besar peserta didik adalah cara menginterpretasi berbagai konsep prinsip fisika sebab mereka dituntut untuk mampu menginterpretasi pengetahuan fisika tersebut secara tepat dan tidak samar-samar atau tidak mendua arti. Sehingga pendidikan fisika harus menjadi pendorong yang kuat tumbuhnya sikap ingin tahu dan keterbukaan terhadap hal baru, maupun kebiasaan berfikir secara kuantitatif. Dalam diri peserta didik sebaiknya ditumbuhkan kesadaran agar dapat melihat fisika semata-mata sebagai kegiatan akademik, tetapi lebih sebagai untuk memahami dunia dimana tempat mereka hidup (Mundilarto, 2002).

Proses sains diturunkan dari langkahlangkah saintis ketika dilakukan penelitian ilmiah, langkah-langkah tersebut dinamakan keterampilan proses sains (Mundilarto, 2002). Keterampilan proses sains dapat juga diartikan sebagai kemampuan atau kecakapan untuk melaksanakan suatu tindakan dalam belajar sains sehingga menghasilkan konsep, teori, prinsip, hukum maupun fakta atau bukti. Mengajarkan keterampilan proses pada peserta didik berarti memberikan kesempatan kepada mereka untuk melakukan sesuatu bukan hanya membicarakan sesuatu tentang sains.

keterampilan proses sains di klasifisikan menjadi keterampilan proses dasar dan keterampilan proses terpadu. Keterampilan proses dasar merupakan fondasi untuk melatihkan proses terpadu yang lebih kompleks. Keterampilan-keterampilan proses sains dasar tersebut adalah: pengklasifikasian (Classifying), pengamatan (Observing), pengukuran (Measuring), peramalan dan penginferensian (Infering and predicting), pengkomunikasian (Communicating), dan melakukan eksperimen (Experimenting).

Keterampilan proses sains merupakan pendekatan dalam pembelajaran Sains yang sangat penting karena berkaitan dengan pengalaman langsung. Pengalaman langsung dapat dilihat melalui pengamatan dan kontak langsung dengan alam sekitar yang menjadi objek belajar. Keterampilan-keterampilan proses sains tersebut, dapat dijelaskan sebagai berikut.

a. Observasi atau Pengamatan 
Observasi atau pengamatan adalah suatu keterampilan ilmiah yang mendasar. Dalam mengobservasi atau mengamati, kita memilah mana yang penting dari yang kurang atau tidak penting. Kita menggunakan semua indera untuk melihat, mendengar, merasa, mengecap, dan mencium. Di dalam mengobservasi tercakup berbagai kegiatan seperti menghitung, mengukur, klasifikasi, maupun mencari hubungan antara ruang dan waktu. Contoh observasi atau pengamatan adalah mengamati perubahan yang terjadi pada perubahan suhu di dalam sebuah thermometer. Jadi mengamati thermometer bukan hanya melihat thermometer itu tetapi memperhatikan dengan seksama bagaimana perubahannya dari perubahan suhu awal ke suhu akhir.

b. Membuat Hipotesis

Kemampuan membuat hipotesis adalah salah satu keterampilan yang sangat mendasar dalam kerja ilmiah. Hipotesis adalah suatu perkiraan yang beralasan untuk menerangkan suatu kejadian atau pengamatan tertentu. Contoh dalam melakukan percobaan kalor, perubahan suhu membutuhkan waktu yang lama mereka dapat membuat hipotesis bahwa waktunya lama karena jumlah massa besar atau kalor yang di berikan kecil.

c. Merancang Penelitian / Percobaan

Para ilmuwan biasanya terbiasa dengan pekerjaan eksperimentasi. Namun kegiatan eksperimen tidak hanya merupakan hal yang mutlak bagi para ilmuwan. Eksperimen adalah usaha menguji atau mengetes melalui penyelidikan yang praktis. Dalam melakukan eksperimen perlu adanya perencanaan agar dalam melakukan pengukuran dapat berjalan dengan lancar. Contohnya jika ingin melakukan percobaan tentang hubungan antara lama pemanasan dengan perubahan suhu maka perlu di rencakan terlebih dahulu percobaan seperti menentukan alat dan bahan, langkah kerja dan bagaimana mencatat dan mengolah data.

d. Pengendalian Variabel

Variabel adalah faktot-faktor yang berpengaruh. Para pendidik dapat melatih anakanak dalam mengendalikan variabel. Contoh pengendalian variable untuk membuktikan bahwa jumlah kalor yang lebih besar akan membuat waktu pemanasan untuk sampai ketitik didih lebih cepat maka perlu di lakukan percobaan dimana percobaan satu di berikan kalor yang lebih besar sedangkan percobaan dua di berikan kalor yang lebih kecil, kemudian hasil keduanya di bandingakan, dan variablevariabel yang di kendalikan adalah massa zat cair dan jenis zat cair yang sama sedangkan variabel yang tergantung adalah jumlah kalor.

e. Interpretasi / Menafsirkan Data

Kemampuan menginterpretasi data adalah salah satu keterampilan penting yang umumnya dikuasai oleh para ilmuwan. Data yang dkumpulkan melalui observasi, perhitungan, pengukuran, eksperimen, atau penelitian sederhana dapat dicatat atau disajikan dalam berbagai bentuk misalnya tabel, grafik, histogram, atau diagram. Data yang disajikan tersebut dapat diinterpretasi atau ditafsirkan. Contoh menginterpretasi data jika di berikan hasil percobaan berupa data lama pemansan dan perubahan suhu dengan massa zat yang berbeda, data tersebut di catat di dalam sebuah tabelatau di di buat dalam bentuk grafik kemudian di interpretasi misalnya bagaimana hubungan antara lama pemanasan dengan perubahan suhu atau bagaimana pengaruh besarnya massa zat pada lama pemanasan

f. Kesimpulan Sementara (Inferensi)

Dalam Para pendidik dapat melatih peserta didik dalam menyusun suatu kesimpulan sementara dalam proses penelitian sederhana yang dilakukan. Pertama-tama data dikumpulkan, kadang-kadang melalui 
eksperimen terlebih dahulu lalu dibuat kesimpulan sementara berdasarkan informasi yang dimiliki sampai suatu waktu tertentu. Kesimpulan tersebut bukan merupakan kesimpulan akhir tetapi hanya merupakan kesimpulan sementara yang dapat diterima sampai pada saat itu. Contoh menginferensi jika di berikan beberapa fenomena alam mengenai suhu dan kalor seperti ketika memasak air di rumah akan lama mendidih karena jumlah airnya banyak dan juga walaupun airnya banyak tetap lama mendidih kerena apinya kecil. Dari itu dapat di inferensi bahwa besarnya massa berpengaruh terhadap lama pemanasan dan besarnya kalor yang di berikan juga berpengaruh.

g. Peramalan atau Prediksi

Meramalkan adalah mencoba mengetahui apa yang akan terjadi di depan dengan memperhatikan gejala-gejala yang ada. Dalam kehidupan sehari-hari, kita sering membuat suatu peramalan berdasarkan pengalaman sebelumnya. Kalau cuaca mendung, kita meramalkan bahwa hujan mungkin akan turun. Kalau angin bertiup kencang selama satu minggu, kita meramalkan bahwa musim kemarau akan segera tiba. Contohnya dalam melakukan percobaan perubahan suhu menggunakan thermometer jika suhu awal adalah 10 derajat suhu kedua adalah 20 derajat maka bias di prediksi bahwa suhu ketiga adalah 30 derajat.

h. Penerapan (aplikasi)

Keterampilan menerapkan atau mengaplikasikan konsep adalah kemampuan yang pada umumnya dimiliki oleh para ilmuwan. Para pendidik dapat melatih peserta didik untuk menerapkan konsep yang telah dikuasai untuk memecahkan masalah tertentu, atau menjelaskan suatu peristiwa yang baru dengan menggunakan konsep yang telah dimiliki. Contoh menerapkan konsep adalah jika di ketahui bahwa konsepnya suhu akan berubah jika di berikan kalor dan lama perubahannya akan di pengaruhi oleh massa dan jenis zat, maka konsep tersebut bisa di terapkan dengan mengubah-ubah massa atau jenis zatnya. Jika di ketahui konsep untuk menghitung besarnya kalor adalah dengan menggunakan rumus kalor maka rumus tersebut dapa di gunakn untuk menghitung besarnya kalor.

i. Komunikasi

Mengomunikasikan merupakan bagian yang terpenting dalam keterampilan proses sains karena data yang di peroleh umumnya bukan untuk untuk keperluan sendiri akan tetapi umum juga perlu mengethui data tersebut. Setiap ilmuwan dituntut agar mampu menyampaian hasil penemuannya kepada orang lain misalnya menyampaikan hasil temuannya kepada orang lain secara lisan, maupun membuat gambar, model, tabel, grafik yang dapat dibaca orang lain (Conny. 1992). Contoh mengomunikasikan adalah jika di peroleh data hasil penelitian tentang hubungan antara lama pemanasan dan perubahan suhu, data tersebut kemudian di ubah ke dalam bentuk grafik atau diagram hubungan lama pemanasan dengan peubahan suhu.

\section{METODE}

Jenis penelitian yang dilakukan adalah penelitian survei. Subjek penelitian adalah peserta didik kelas XI IPA SMA Negeri se-kab. Jeneponto yang berjumlah 80 orang. Teknik pengumpulan data yang digunakan adalah tes berupa tes pengetahuan peserta didik menggunakan instrumen. Defenisi operasional variabel keterampilan proses sains merupakan skor yang diperoleh peserta didik setelah diberikan lembar tes dengan indikator meramalkan, menafsirkan menerapkan konsep dan mengomunikasikan. Teknik analisis data 
dalam penelitian ini semuanya diolah dengan menggunakan teknik statistik deskriptif. Teknik deskriptif ini digunakan untuk mendeskripsikan karakteristik skor hasil belajar fisika. Hasil tersebut ditampilkan dalam bentuk skor tertinggi, skor terendah, skor rata-rata dan deviasi standar. Instrumen tes digunakan untuk mengetahui gambaran keterampilan proses sains pada saat pembelajaran berlangsung. Adapun tahapan analisisnya adalah sebagai berikut:

1) Menjumlahkan indikator dari aspek KPS yang diamati

2) Menghitung persentase aspek KPS dalam kelompok dengan rumus:

$$
\text { persentase }=\frac{\text { skor hasil observasi }}{\text { skor total }} \times 100 \%
$$

Data yang telah didapat dari hasil analisis data berupa lembar observasi kemudian dikonversikan dalam kategori nilai persentase dan dapat dilihat pada tabel 1 .

Tabel.1 Kategori Keterampilan Proses Sains

\begin{tabular}{cc}
\hline Interval Skor & Kategori \\
\hline $28-35$ & Sangat Tinggi \\
$21-27$ & Tinggi \\
$14-20$ & Cukup \\
$7-13$ & Rendah \\
$0-6$ & Sangat Rendah \\
\hline
\end{tabular}

\section{HASIL DAN PEMBAHASAN}

\section{a. Hasil Penelitian}

Tes pengukuran keterampilan proses sains di lakukan terhadap 80 responden dengan pembagian ada 40 responden di SMAN akreditasi A, 20 responden di SMAN akreditasi B dan 20 responden di SMAN akreditasi C. Dengan hasil pengkategorian seperti pada tabel berikut ini.
Tabel. 2 Statistik keterampilan proses sains fisika peserta didik di kab. jeneponto

\begin{tabular}{cccc}
\hline $\begin{array}{c}\text { Interval } \\
\text { Skor }\end{array}$ & $\begin{array}{c}\text { Freku } \\
\text { ensi }\end{array}$ & $\begin{array}{c}\text { Persent } \\
\text { ase (\%) }\end{array}$ & Kategori \\
\hline $28-35$ & 0 & 0.00 & Sangat Tinggi \\
$21-27$ & 34 & 42.50 & Tinggi \\
$14-20$ & 43 & 53.75 & Cukup \\
$7-13$ & 3 & 3.75 & $\begin{array}{c}\text { Rendah } \\
\text { Sangat } \\
\text { Rendah }\end{array}$ \\
\hline Jumlah & 80 & 100 & \\
\hline
\end{tabular}

Dari tabel keterampilan proses sains fisika peerta didik di atas menunjukkan bahwa ada 34 orang yang memiliki skor yang berkategori baik dengan persentase $42,50 \%, 43$ orang berkategori cukup dengan persentase $53,75 \%$ dan 3 orang berkategori rendah dengan persentase $3,75 \%$. Dengan demikian keterampilan proses sains fisika peserta didik di kabupaten jeneponto tergolong dalam kategori cukup yaitu 53,75\%.

Berdasarkan tiap akreditasi sekolah dapat di tampilkan perbandingannya pada tabel dan grafik berikut ini.

Tabel. 3 Perbandingan keterampilan proses sains fisika peserta didik sman di kabupaten jeneponto

\begin{tabular}{ccc}
\hline sekolah & skor rata-rata & persentase \\
\hline Akreditasi A & 21,78 & tinggi \\
Akreditasi B & 19,80 & cukup \\
Akreditasi C & 18,15 & cukup \\
\hline
\end{tabular}

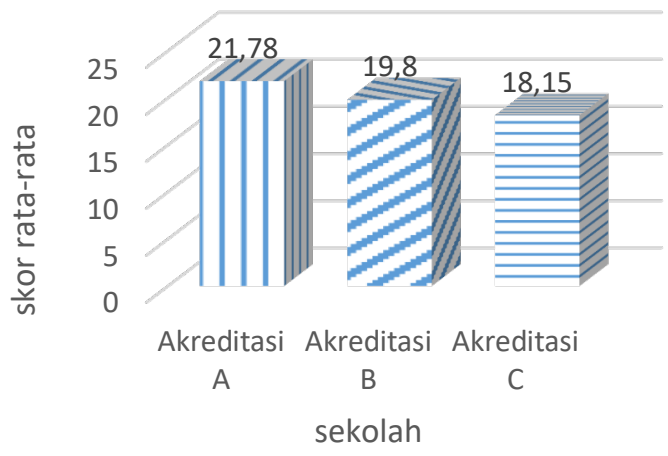

Gambar .1 Diagram perbandingan keterampilan proses sains fisika peserta didik di kab. Jeneponto 
Grafik di atas menunjukkan bahwa keterampilan proses sains fisika peserta didik SMAN di kab. Jeneponto, SMAN akreditasi A memiliki kriteria baik dengan persentase $77 \%$, SMAN akreditasi B memiliki kriteria cukup dengan persentase $85 \%$ dan SMAN akreditasi $\mathrm{C}$ memiliki kriteria cukup dengan persentase $75 \%$. Dengan demikian, SMAN yang berakreditasi A memiliki kriteria lebih baik dari pada SMAN yang berakreditasi B dan C, serta SMAN berakreditasi B lebih baik di banding yang berakreditasi $\mathrm{C}$.

Data keterampilan proses sains fisika peserta didik berdasarkan tiap indikator di tampilkan seperti berikut ini.

1) Menafsirkan

Tabel 4 Perbandingan keterampilan proses sains fisika peserta didik di kab. jeneponto dalam menafsirkan

\begin{tabular}{ccc}
\hline Sekolah & $\begin{array}{c}\text { skor rata- } \\
\text { rata }\end{array}$ & kategori \\
\hline Akreditasi A & 5,15 & cukup \\
Akreditasi B & 4,70 & cukup \\
Akreditasi C & 4,20 & rendah \\
\hline
\end{tabular}

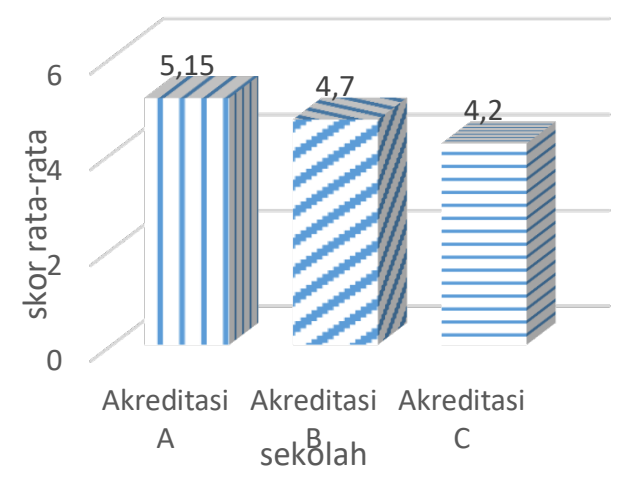

Gambar 2 Diagram perbandingan keterampilan proses sains fisika peserta didik SMAN di Kab. Jeneponto dalam menafsirkan

Grafik di atas menunjukkan bahwa keterampilan proses sains fisika peserta didik SMAN di kab. Jeneponto dalam menafsirkan data, SMAN akreditasi A memiliki kriteria cukup dengan persentase $87 \%$, SMAN akreditasi Bmemiliki kriteria cukup dengan persentase $70 \%$ dan SMAN akreditasi C memiliki kriteria rendah dengan persentase $65 \%$. Dengan demikian, SMAN yang berakreditasi A memiliki kriteria lebih baik dalam menafsirkan data dari pada SMAN yang berakreditasi $B$ dan $C$, serta SMAN berakreditasi B lebih baik di banding yang berakreditasi $\mathrm{C}$.

2) Meramalkan

Tabel 5 Perbandingan keterampilan proses sains fisika peserta didik di kab. Jeneponto dalam meramalkan

\begin{tabular}{ccc}
\hline Sekolah & skor rata-rata & kategori \\
\hline Akreditasi A & 5,80 & cukup \\
Akreditasi B & 5,25 & cukup \\
Akreditasi C & 4,95 & cukup \\
\hline
\end{tabular}

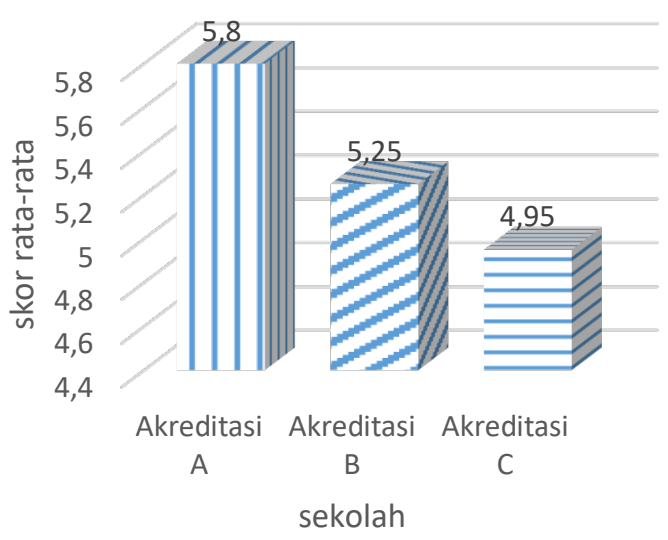

Gambar 3 Diagram perbandingan keterampilan proses sains fisika peserta didik SMAN di

Kab. Jeneponto dalam meramalkan

Grafik di atas menunjukkan bahwa keterampilan proses sains fisika peserta didik SMAN di kab. Jeneponto dalam meramalkan data, SMAN akreditasi A memiliki kriteria cukup dengan persentase $75 \%$, SMAN akreditasi B memiliki kriteria cukup dengan persentase $80 \%$ dan SMAN akreditasi C memiliki kriteria cukup dengan persentase $70 \%$. Dengan demikian, SMAN yang berakreditasi B memiliki kriteria lebih baik dalam meramalkan dari pada SMAN yang berakreditasi A dan C, serta SMAN berakreditasi A lebih baik di banding yang berakreditasi $\mathrm{C}$. 
3) Menerapkan konsep

Tabel 6 Perbandingan keterampilan proses sains fisika peserta didik di kab. jeneponto dalam menerapkan konsep

\begin{tabular}{ccc}
\hline Sekolah & skor rata-rata & kategori \\
\hline Akreditasi A & 5,92 & cukup \\
Akreditasi B & 5,55 & cukup \\
Akreditasi C & 5,60 & cukup \\
\hline
\end{tabular}

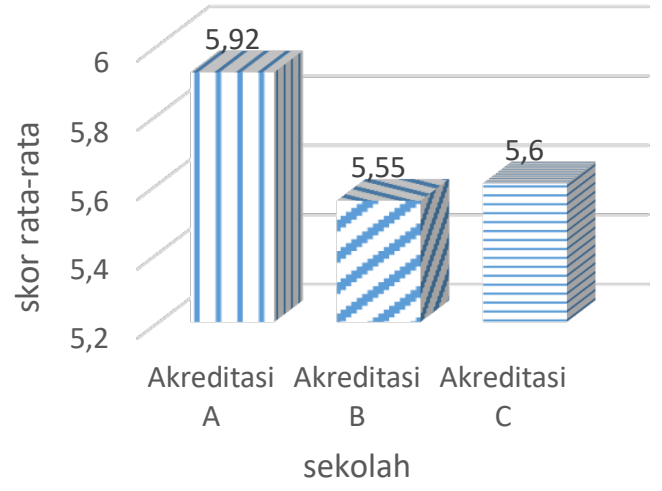

Gambar 4 Diagram perbandingan keterampilan proses sains fisika peserta didik SMAN di Kab. Jeneponto dalam menerapkan konsep

Grafik di atas menunjukkan bahwa keterampilan proses sains fisika peserta didik SMAN di kab. Jeneponto dalam menerapkan konsep, SMAN akreditasi A memiliki kriteria cukup dengan persentase $73 \%$, SMAN akreditasi B memiliki kriteria cukup dengan persentase $70 \%$ dan SMAN akreditasi $\mathrm{C}$ memiliki kriteria cukup dengan persentase 55\%. Dengan demikian, SMAN yang berakreditasi A memiliki kriteria lebih baik dalam menerapkan konsep dari pada SMAN yang berakreditasi $\mathrm{B}$ dan $\mathrm{C}$, serta SMAN berakreditasi $\mathrm{B}$ lebih baik di banding yang berakreditasi $\mathrm{C}$.

4) Mengomunikasikan

Tabel 7 Perbandingan keterampilan proses sains fisika peserta didik di kab. jeneponto dalam menerapkan kons

\begin{tabular}{ccc}
\hline Sekolah & skor rata-rata & kategori \\
\hline Akreditasi A & 4,85 & tinggi \\
Akreditasi B & 4,30 & cukup \\
Akreditasi C & 3,50 & cukup \\
\hline
\end{tabular}

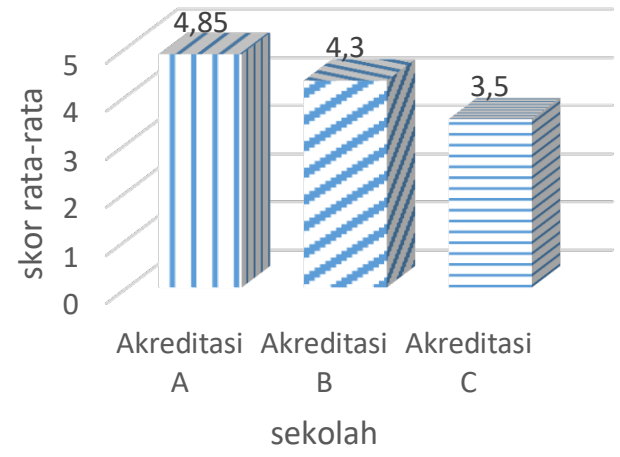

Gambar 5 Diagram perbandingan keterampilan proses sains fisika peserta didik SMAN di Kab. Jeneponto dalam mengomunikasikan

Grafik di atas menunjukkan bahwa keterampilan proses sains fisika peserta didik SMAN di kab. Jeneponto dalam mengomunikasikan, SMAN akreditasi A memiliki kriteria baik dengan persentase $50 \%$, SMAN akreditasi B memiliki kriteria cukup dengan persentase $60 \%$ dan SMAN akreditasi $\mathrm{C}$ memiliki kriteria cukup dengan persentase $45 \%$. Dengan demikian, SMAN yang berakreditasi A memiliki kriteria lebih baik dalam megomunikasikan dari pada SMAN yang berakreditasi $\mathrm{B}$ dan $\mathrm{C}$, serta SMAN berakreditasi $\mathrm{B}$ lebih baik di banding yang berakreditasi $\mathrm{C}$.

\section{b. Pembahasan}

Ide awal penelitian ini adalah adanya sejumlah teori atau pandangan yang menyatakan bahwa keterampilan proses sains sangatlah menentukan dan menunjang hasil belajar peserta didik di sekolah sejalan dengan hasil penelitian yang di lakukan oleh (Purnama, 2014) menunjukkan keterampilan proses sains peserta didik yang diajar dengan menggunakan pendekatan ilmiah lebih baik dibandingkan dengan kelas yang diajar tanpa menggunakan pendekatan ilmiah dan di dukung oleh penelitian yang di lakukan oleh (Suryaningsih, 2016) bahwa pembelajaran dengan menerapkan kegiatan ilmiah sangat penting perannya dalam meningkatkan keterampilan proses sains. 
Dengan demikian, penulis memiliki keinginan untuk mengetahui bagaimana gambaran keterampilan proses sains peserta didik SMA se-Kabupaten Jeneponto kelas XI di sekolah yang memiliki akreditasi yang berbeda yaitu akrditasi A, B dan C. Selanjutnya di lakukan observasi lapangan untuk menentukan sampel dan di gunakan teknik pengambilan sampel yaitu teknik Proportionate Stratified Random Sampling. Keterampilan proses sains pada dasarnya ada 9 indikator namun pada penelitian ini peneliti hanya mengambil 4 indikator untuk diteliti yaitu indikator menafsirkan data, meramalkan, menerapkan konsep dan mengomunikasikan data.

Analisis data hasil pengukuran keterampilan proses sains fisika peserta didik di SMAN se-kabupaten Jenepoonto menunjukkan bahwa dari 80 sampel terdapat 34 orang atau sampel yang memiliki skor perolehan dengan kategori tinggi, 43 orang memilki skor perolehan dengan kategori cukup, dan 3 orang memilki skor perolehan dengan kategori rendah. Dengan demikian skor keterampilan proses sains fisika peserta didik di kabupaten Jeneponto tergolong dalam kategori cukup dengan skor rata-rata 20,55 dengan skor maksimum ideal yaitu 35 , skor minimum ideal 0 , skor maskimum 24 dan skor minimum yaitu 14.

Keterampilan proses sains fisika peserta didik tiap akreditasi juga menunjukkan hasil yang berbeda-beda, sekolah yang berakreditasi A memiliki keterampilan proses sains fisika yang lebih tinggi dari pada sekolah yang berakreditasi $\mathrm{B}$ dan $\mathrm{C}$, serta sekolah berakreditasi B lebih baik di banding sekolah yang berakreditasi C. Hasil ini sesuai dengan hasil penelitian yang di lakukan oleh (khaerunnisa, 2017) bahwa Penyebab keterampilan proses sains (fisika) SMA kategori A lebih unggul dibandingkan keterampilan proses sains (fisika) SMA kategori B adalah karena kurang fasilitas dalam melakukan praktikum pada SMA kategori B yang mengakibatkan pendidik hanya berfokus pada teori tanpa adanya pemberian praktikum.

Empat indikator keterampilan proses sains yang di gunakan dalam penelitian ini pun menunjukkan hasil yang bereda-beda tiap akreditasi. Dimana pada indikator menafsirkan, meramalkan, menerapkan konsep dan mengiomunikasikn sekolah yang berakreditasi A memiliki kriteria lebih baik dalam menafsirkan data dari pada sekolah yang berakreditasi $\mathrm{B}$ dan $\mathrm{C}$, serta sekolah berakreditasi $\mathrm{B}$ lebih baik di banding yang berakreditasi C. Pada indikator menafsirkan keterampilan proses sains fisika peserta didik berada pada kategori cukup semua akreditasi yang berbeda hanya pada skor rata-ratanya. Dari semua indikator yang di gunakan, sekolah yang berakreditasi A memilki skor rata-rata yang lebih tinggi di bandingkan sekolah yang berakreditasi $\mathrm{B}$ dan $\mathrm{C}$, dan sekolah yang berakreditasi B lebih tinggi dari sekolah yang berakreditasi $\mathrm{C}$.

Data di atas memperlihatkan bahwa keterampilan proses sains fisika peserta didik SMAN di Kab. Jeneponto berada pada kategori cukup dengan skor rata-rata 20,55. Kategori ini di sebabkan oleh beberapa faktor diantaranya adalah keadaan latar belakang peserta didik yang kebanyakan berada di pedesaan dengan semangat dan motivasi belajar yang kurang sebagaiman di peroleh oleh (Salmi, 2017) dalam penelitiannya bahwa perlu sebuah metode yang pembelajaran yang sesuai agar keterampilan proses dapat meningkat. Selanjutnya kurangnya sarana praktikum dan kegiatan praktikum yang di lakukan di sekolah Hal ini sesuai dengan pernyataan (Kurnia, 2010) yang menyatakan bahwa rendahnya kemampuan keterampilan proses sains siswa 
dipengaruhi oleh beberapa faktor, diantaranya kurikulum dan sistem pendidikan, pemilihan metode dan model pengajaran oleh guru, sarana dan fasilitas belajar, sumber belajar, dan lainlain dan juga hasil penelitian (Anugerah, 2018) bahwa faktor yang mempengaruhi adalah pengalaman peserta didik dalam pelaksanaan praktikum fisika dan pengetahuan mengenai keterampilan proses sains. Serta kemungkinan lain adalah karena pada penelitian ini tidak di lakukan proses pembelajaran terlebih dahulu seperti yang di kemukakan Jack dalam (Eka Ningsih Dkk, 2015) yang menyatakan bahwa keterampilan proses sains siswa yang rendah disebabkan oleh beberapa faktor meliputi: rendahnya latar belakang sains dan minimnya prasarana laboratorium. Untuk dapat meningkatkan keterampilan proses sains peserta didik diperlukan model atau metode pembelajaran yang tepat. Selain itu pengetahuan awal mengenai konsep fisika dan KPS pada diri peserta didik sebelum di berikan instrumen juga akan menjadi dasar dalam pembentukan keterampilan proses sains. Hal tersebut sejalan dengan yang dikatakan (Myers dan Jamers, 2006) bahwa pentingnya pengetahuan awal dalam pembentukan pemahaman yang lebih tinggi.

\section{REFERENSI}

Anugerah, 2018. Analisis Keterampilan Proses Sains Dalam Pembelajaran Fisika Di Sma Negeri 17 Makassar. Tidak di terbitkan: Jurusan Pendidikan Fisika. FMIPA UNM.

Eka Ningsih, Puji, Siswoyo dan I Made Astra. 2015. Pengaruh Metode Pogil (Process Oriented Guided Inquiry Learning) Terhadap Keterampilan Proses Sains Siswa pada Materi Suhu dan Kalor Kelas X SMA. Jurnal Fisika, Vol. 04, ISSN: 2339-0654.

Khaerunnisa, 2017. Analisis Keterampilan Proses Sains (Fisika) SMA Di Kabupaten

\section{KESIMPULAN}

Berdasarkan hasil penelitian yang telah di lakukan maka peneliti dapat menyimpulkan bahwa:

1. Keterampilan proses sains fisika peserta didik SMAN di Kabupaten Jeneponto tahun ajaran 2018/2019 semester ganjil berada pada kategori cukup.

2. Keterampilan proses sains fisika peserta didik pada sekolah terakreditasi A memiliki skor rata-rata yang lebih tinggi dibandingkan peserta didik yang berasal dari sekolah yang berakreditasi B dan C, dan peserta didik dari sekolah terkreditasi B memiliki skor rata-rata yang lebih tinggi dibandiingkn peserta didik yang berasal dari sekolah yang berakreditasi $\mathrm{C}$.

3. Dari semua indikator yang di gunakan, sekolah yang terakreditasi A memilki skor rata-rata yang lebih tinggi dibandingkan sekolah yang terakreditasi B dan C, dan sekolah yang terakreditasi $\mathrm{B}$ lebih tinggi dari pada sekolah yang terakreditasi C.

Jeneponto. Jurnal Pendidikan fisika. vol 5. No. 3. Unismuh Makassar.

Kurnia, E. 2010. Analisis Keterampilan Proses Sains Siswa SMA Pada Pembelajaran Sistem Koloid Menggunakan Metode Praktikum Berbasis Masalah. Jurusan Pendidikan Kimia, Universitas Pendidikan Indonesia, Bandung.

Mundilarto (2002). Kapita Selekta Pendidikan Fisika. Yogyakarta: FMIPA UNY .

Myers, B. E., Dyer, J. E., 2006. Effects of Investigative Laboratory Instruction on Content Knowledge and Science Process Skill Achievement Across Learning 
Styles. Journal of Agricultural Education. 42 (4): 52-63.

Purnama, Tiara. 2014. Pengaruh Pendekatan Ilmiah Dalam Pembelajaran Fisika Terhadap Keterampilan Proses Sains Peserta Didik Kelas X Sman 1 Marioriwawo Kabupaten Soppeng. Jurnal Sains dan Pendidikan Fisika, Vol 11, no 2 (hal. 155-160). FMIPA UNM.

Salmi, Novita. 2017. Penerapan Model Pembelajaran Berbasis Proyek Terhadap Motivasi Belajar Fisika
Dan Keterampian Proses Sains Peserta Didik Sman 4 Makassar. Jurnal Sains dan Pendidikan Fisika. Vol 13 No 3 (hal. 238-247). FMIPA UNM.

Suryaningsih, Kumala. 2016. Peningkatan Keterampilan Proses Fisika Melalui Pendekatan Ilmiah Peserta Didik Kelas X SMAN Negeri 1 Makassar. Jurnal Sians dan Pendidikan Fisika, Vol 12 No 1. (hal. 30-36). FMIPA UNM.

Sutrisno. 2006. Fisika dan Pembelajarannya. Bandung: Jurusan Fisika FMIPA UPI. 